Research Paper

\title{
Limnology of the neotropical high elevation shallow lake Yahuarcocha (Ecuador) and challenges for managing eutrophication using
} biomanipulation

\author{
Willem Van Colen ${ }^{\mathrm{a}, *}$, Karen Portilla ${ }^{\mathrm{b}}$, Tania Oña ${ }^{\mathrm{b}}$, Guido Wyseure ${ }^{\mathrm{c}}$, Peter Goethals ${ }^{\mathrm{d}}$, \\ Elizabeth Velarde ${ }^{\mathrm{b}}$, Koenraad Muylaert ${ }^{\mathrm{a}}$

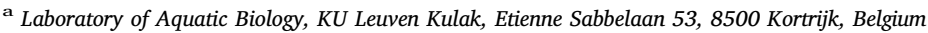 \\ b Faculty of Agricultural and Environmental Engineering, Department of Natural Resource Management (FICAYA), Universidad Tecnica del Norte (UTN), Avenida 17 de \\ Julio, 5-21, y Gral José María Cordova, EC100150 Ibarra, Ecuador \\ ${ }^{\mathrm{c}}$ Division of Soil and Water Management, KU Leuven, Celestijnenlaan 200e, 3001 Leuven, Belgium \\ d Centre Environmental Science and Technology (CES \& T), Ghent University, J. Plateaustraat 22, 9000 Ghent, Belgium
}

\section{A R T I C L E I N F O}

\section{Keywords:}

Andean lakes

Alternative stable states

Lake restoration

Algal blooms

Cylindrospermopsis

Top-down control

\begin{abstract}
A B S T R A C T
Temperate and tropical shallow lakes differ in several fundamental aspects with respect to management of eutrophication. High altitude tropical shallow lakes are a special case, showing similarities with temperate and tropical lakes. We studied the ecology of the eutrophic high-altitude tropical lake Yahuarcocha in the Ecuadorian Andes and evaluated the potential of biomanipulation to control eutrophication. With a toxin-producing Cylindrospermopsis bloom, low Secchi depth and low submerged macrophyte cover, Yahuarcocha is clearly in a turbid ecosystem state. Relatively low nutrient concentrations should theoretically allow for a shift to a clear water state through biomanipulation. Top-down control of phytoplankton by zooplankton, however, is complicated by the (1) absence of predatory fish, (2) fish community dominated by small poecelid species, (3) lack of a refuge for zooplankton from fish predation within the macrophytes, and (4) persistent, grazing resistant bloom of the cyanobacterium Cylindrospermopsis. In these aspects, lake Yahuarcocha is more similar to tropical shallow lakes, probably because water temperature is high relative to the mean air temperature and because of the absence of a cold season. The fish and macrophyte communities consisted almost entirely of exotic species. The exotic fish species probably stabilized the turbid state in the lake.
\end{abstract}

\section{Introduction}

Shallow lakes are the most common type of lakes around the world and represent a significant fraction of the total surface water on earth (Downing et al., 2006). They provide important ecosystem services such as provision of drinking water, irrigation, recreation or fisheries (Landuyt et al., 2014) and support a high biodiversity (Moss, 2000; Williams et al., 2003). In the past half century, many shallow lakes have suffered from eutrophication and algal blooms (Smith, 2003).

Pristine shallow lakes often have clear water and a vegetation of submerged macrophytes. Upon eutrophication, turbidity of the water increases, submerged macrophytes disappear and the lake shifts from a clear to a turbid regime. A reduction in nutrient inputs is often insufficient to reduce turbidity and restore the clear water state (Hobbs et al., 2012). This hysteresis in the response of turbidity to nutrients is due to the fact that the clear and turbid states are stabilized by feedback mechanisms. Restoration of the clear water state can be achieved through biomanipulation: abundance of planktivorous fish is reduced to achieve an increase in zooplankton density, which can in turn control of phytoplankton biomass (Carpenter et al., 1995). The control of phytoplankton by zooplankton reduces turbidity and allows submerged macrophytes to re-colonize the lake. Once a submerged macrophytes vegetation has been established, the clear water state is stabilized by feedback mechanisms. One important feedback mechanism is that macrophytes offer a refuge to large zooplankton like Daphnia spp. from fish predation, which allows zooplankton to control phytoplankton biomass (Burks et al., 2001). Biomanipulation can only be effective however if external nutrient inputs are reduced and internal eutrophication by nutrients stored in sediments is minimal (e.g. Hobbs et al., 2012; Jeppesen et al., 2012).

Most of our understanding on the ecology of shallow lakes is based on research in temperate climate regions (Europe, North America). In

\footnotetext{
* Corresponding author.

E-mail address: willem.vancolen@kuleuven.be (W. Van Colen).
} 
the past decade, research has been initiated in warmer climate regions such as tropical and subtropical South America (e.g. Jeppesen et al., 2007; Kosten et al., 2009). This has revealed some important differences in the functioning of shallow lakes between temperate and (sub) tropical climates. Shallow lakes in (sub)tropical climates tend to shift from a clear to a turbid state at lower nutrient levels than in a temperate climate (Kosten et al., 2009). Subtropical or tropical climates also tend to favor cyanobacterial blooms (Joehnk et al., 2008; Kosten et al., 2012), which can persist for many years (e.g. Figueredo and Giani, 2009). Grazing control by zooplankton is often impaired by the morphology and production of toxic metabolites in cyanobacteria making them low quality food (Hansson et al., 2007). Moreover, the response of cyanobacteria to grazing can be highly taxa-specific (Urrutia-Cordero et al., 2016). The fish communities of (sub)tropical lakes are in many cases dominated by small omnivorous species that live within macrophyte beds rather than in the open water (Meerhoff et al., 2007; Teixeira de Mello et al., 2009; Iglesias et al., 2011). As a result, submerged macrophytes do not offer an efficient refuge for zooplankton from fish predation like they do in temperate lakes. These differences in functioning between temperate and (sub)tropical shallow lakes have crucial implications for the management strategies developed to control eutrophication.

Shallow lakes situated at high elevation near the equator form a special case. High elevation tropical shallow lakes share similarities with tropical (lack of seasonality, with no real winter season) as well as temperate lakes (a permanent temperate climate). Although being rare on a global scale, this situation is not uncommon in the Andes mountains of South America. In the inter-Andean valleys, alluvial deposits have created high altitude plains on which shallow lakes have formed (Sarmiento et al., 2008). These ecosystems are isolated from the lowerlying areas by the peaks of the Andes and hence often have unique endemic bird or fish species (Anderson and Maldonado-Ocampo, 2011). Because a lot of large cities are also located within the inter-Andean valleys, these shallow lakes are suffering from increasing eutrophication and measures are needed to restore these lakes to more pristine conditions. In order to develop sustainable restoration measures, there is an urgent need for more information on the functioning of these high elevation shallow lakes. This study focuses on the eutrophic high elevation shallow lake Yahuarcocha, which is situated near the equator in the inter-Andean valley of Ecuador. The main goal of this study was to compare the structure and functioning of this shallow lake with temperate and (sub)tropical shallow lakes and to assess the potential to use biomanipulation with the aim of reducing eutrophication.

\section{Materials and methods}

\subsection{Study site}

Yahuarcocha lake is a relatively large $\left(2.6 \mathrm{~km}^{2}\right)$ shallow lake situated near the city of Ibarra in Northern Ecuador (Table 1). The lake is

Table 1

Morphometric and climatological data of lake Yahuarcocha.

\begin{tabular}{ll}
\hline Parameter & Value \\
\hline Latitude (N) & $00^{\circ} 22^{\prime}$ \\
Longitude (W) & $78^{\circ} 06^{\prime}$ \\
Elevation (m.a.s.l.) & 2192 \\
Catchment area $\left(\mathrm{km}^{2}\right)$ & 21.2 \\
Lake area $\left(\mathrm{km}^{2}\right)$ & 2.6 \\
Maximum depth (m) & 7.1 \\
Mean depth (m) & 4.9 \\
Lake volume $\left(10^{6} \mathrm{~m}^{3}\right)$ & 12.7 \\
Mean/median day air T $\left({ }^{\circ} \mathrm{C}\right)$ & $17.7 / 18.0$ \\
10th/90th percentile & $16.3 / 18.7$ \\
Mean/median annual precipitation $\left(\mathrm{mm}^{2}\right.$ year & $-1)$ \\
10th/90th percentile & $619 / 630$ \\
& $437 / 789$ \\
\hline
\end{tabular}

most likely of glacial origin. It is situated just north of the equator $\left(0^{\circ}\right.$ $22^{\prime} \mathrm{N}, 78^{\circ} 06 \mathrm{~W}$ ) at an altitude of $2191 \mathrm{~m}$. The lake was the site of a determining battle between the Inca and Caranqui in the year 1478 and is therefore of high cultural importance. The lake is surrounded by numerous restaurants that attract about 20000 visitors each weekend. The lake has been eutrophic for many years, probably due to combination of nutrients inputs from the tourism industry and from agriculture. Yahuarcocha is a habitat for numerous aquatic bird species such as Anas georgica, Oxyura ferruginea, Actitis macularius, Larus serranus, Porphyrula martinica, Porzana carolina, Phalacrocorax brasilianus, Podylimbus podiceps and several species of egrets (Ardea alba, Bubulcus ibis, Butorides striatus, Egretta thula and Nycticorax nycticorax).

\subsection{Monthly monitoring}

The lake was sampled on a monthly basis between March 2014 and March 2015. Samples were collected near the deepest point in the lake. Conductivity, $\mathrm{pH}$, temperature and oxygen concentrations were measured using a multiparameter probe (YSI Professional Plus) with a depth interval of $1 \mathrm{~m}$. Secchi depth was recorded using a $30 \mathrm{~cm}$ diameter black and white disc. An unfiltered water sample was taken for total nitrogen (TN) and phosphorus (TP). A filtered water sample (Whatman $\mathrm{GF} / \mathrm{F}$ filter, $25 \mathrm{~mm}, 0.7 \mu \mathrm{m}$ pore size) was taken for measurements of dissolved inorganic nitrogen (DIN: measured as sum of nitrate/nitrite and ammonium) and soluble reactive phosphorus (SRP). Both samples were stored frozen until analysis with a QuAAtro segmented flow analyser (Seal Analytical, Norderstedt, Germany). Samples for TN and TP were digested prior to analysis using an alkaline persulphate digestion, converting all nitrogen and phosphorus to nitrate and orthophosphate respectively. Additional nutrient analyses were carried out on a dissolved nutrient sample after digestion to obtain concentrations of total dissolved N and P. Samples for analysis of chlorophyll $a$ (Chl $a$ ) and carotenoids were collected by filtering a known volume of lake water over a Whatman GF/F filter. The filter containing the algae was stored frozen until analysis. Pigments were extracted from the GF/F filters in $90 \%$ methanol using ultrasonication. The carotenoid trans- $\beta$ apo-8'-carotenol was added during the extraction as an internal standard. Pigments were separated and quantified on a Waters Alliance HPLC system equipped with a Waters Spherisorb ODS2 column using a ternary gradient of 80:20 methanol $0.5 \mathrm{M}$ ammonium acetate, 90:10 acetonitrile water and ethyl acetate. Carotenoids were identified using a PDA detector and the system was calibrated using pure standards (DHI, Denmark). For analysis of phytoplankton community composition, a water sample was filtered over $64 \mu \mathrm{m}$ Nitex mesh to remove large zooplankton species, fixed with formalin (final concentration of 4\%) and stored in the dark at room temperature until analysis. Counting was done using inverted microscopy using $10 \mathrm{~mL}$ settling chambers. At least 100 individuals and colonies observed along radial transects were counted identified up to genus level. Zooplankton was sampled using a tow net $(64 \mu \mathrm{m}$ mesh size). The zooplankton sample was fixed with formalin (final concentration of 4\%) and stored in the dark at room temperature until analysis. Using a stereomicroscope, 150 individuals of each sample were identified up to genus level (and species level where possible).

\subsection{Additional data collection}

Climatological data for the period 1972-2009 were obtained from a nearby weather station (Atahualpa Airport, Ibarra). In August 2013, the bathymetry of the lake was mapped using a GPS-sonar module (GPSmap 526s, Garmin). The entire lake area was divided into transects separated approx. $50 \mathrm{~m}$ and a bathymetrical map was constructed using GIS. The macrophyte vegetation (submerged, floating and emergent) was also mapped in August 2013. All plant species were identified up to species level and their relative abundance and extent of coverage was estimated. 

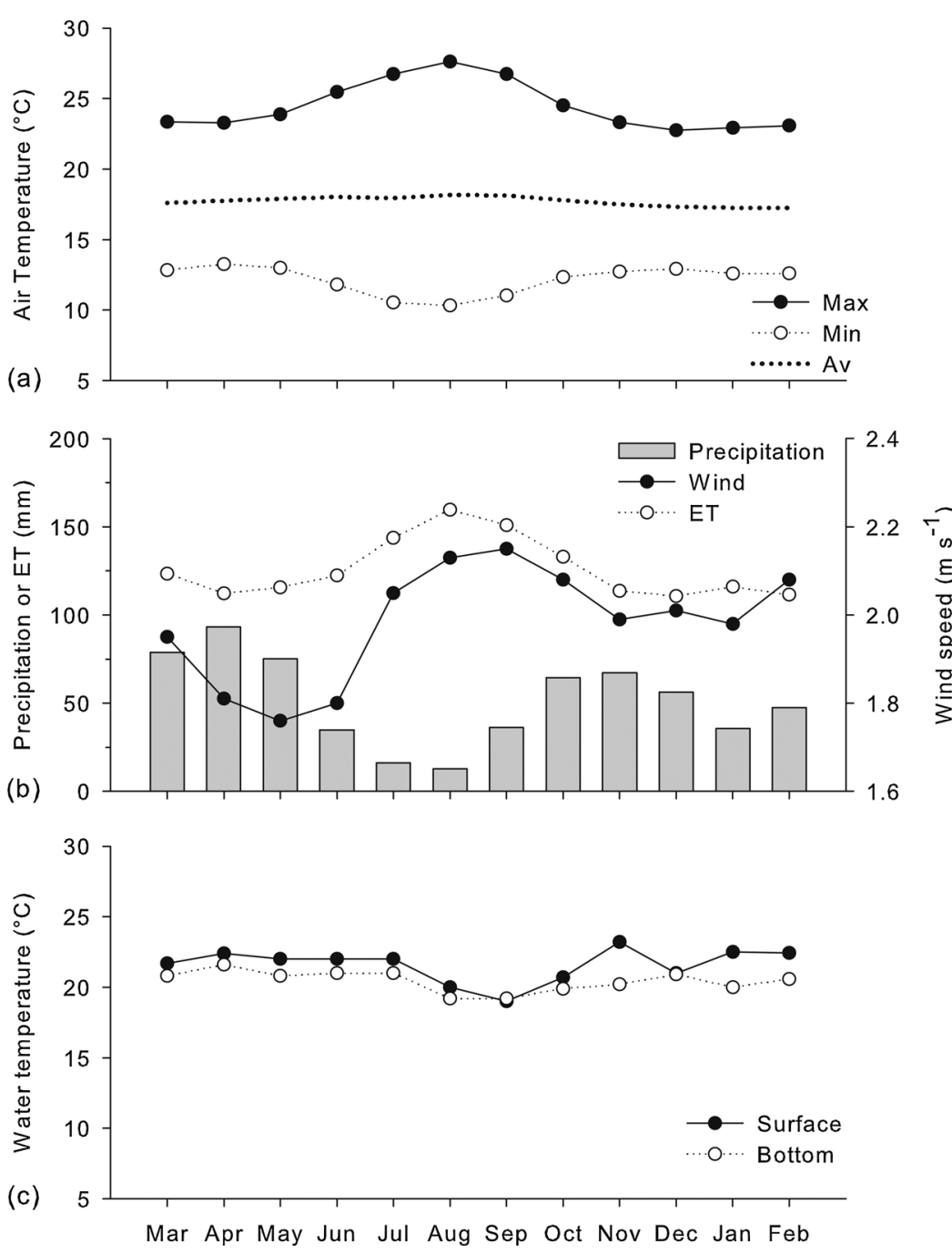

In August 2014, a sample of Cylindrospermopsis was collected to determine the presence of the cyanotoxin cylindrospermopsin. A large volume of water was filtered through a $20 \mu \mathrm{m}$ Nitex mesh until a few milliliter of wet algal biomass was collected. Three samples were collected at different sites near the lake shore. This wet biomass was stored frozen $\left(-20^{\circ} \mathrm{C}\right)$ and later freeze-dried. The dried powder $(15 \mathrm{mg})$ was extracted in mixture of methanol/0.1 M aqueous acetic acid $(1 \mathrm{~mL}$, $75: 25, \mathrm{v} / \mathrm{v}$ ) by bead-milling for $30 \mathrm{~min}$. The biomass was removed by centrifugation and the supernatant was filtered through a $0.22-\mu \mathrm{m}$ filter. Cylindrospermopsin was analyzed by LC-MS/MS using ultra-high pressure liquid chromatography (UHPLC) coupled to an API 5500 QTRAP triple-quadrupole mass spectrometer (AB Sciex, France) in positive ion mode with multiple reaction monitoring detection. Separation was done on a $15 \mathrm{~cm}$ TSK gel Amide- 80 column (TOSOH Science) with Milli-Q water (A) and acetonitrile (B) as mobile phases, both containing $0.1 \%$ acetic acid (gradient: $10 \%$ A rising to $55 \%$ A over 7 min and rising again to $100 \%$ over $0.5 \mathrm{~min}$; flow rate was $0.3 \mathrm{~mL} \mathrm{~min}^{-1}$; injection volume was $5 \mu \mathrm{L}$ ). The ESI interface was operated using the following parameters: curtain gas 25 psi; temperature $500{ }^{\circ} \mathrm{C}$; gas1 30 psi; gas2 70 psi; ion spray voltage $5500 \mathrm{~V}$. Cylindrospermopsin was detected based on a $m / z$ ratio of 416 for the precursor ion and $m / z$ ratios of 176,336 and 163 . The $m / z 163$ ion was used for quantification and the limit of quantification (LoQ) was $0.67 \mu \mathrm{g} \mathrm{g}^{-1}$.

In February 2015, the fish community in the lake was sampled on one occasion using a single multi mesh-size gill net. A net of $30 \mathrm{~m}$ wide and $1.5 \mathrm{~m}$ high was positioned randomly in the open water of the lake for a period of $18 \mathrm{~h}$. The net consisted of 12 equally size panels with
Fig. 1. Climate. Graph showing (a) mean monthly minimum and maximum day temperature $\left({ }^{\circ} \mathrm{C}\right.$ ) and mean monthly temperature, (b) precipitation ( $\mathrm{mm}$ ), wind speed $\left(\mathrm{m} \mathrm{s}^{-1}\right)$ and evapotranspiration (ET, $\mathrm{mm}$ ) and (c) water temperatures $\left({ }^{\circ} \mathrm{C}\right.$ ) at the surface and bottom throughout the year. Data in (a) and (b) were measured monthly from 1972 up to 2009. Data of (c) was measured during the survey (March 2014-February 2015). mesh sizes varying from 6.25 to $55 \mathrm{~mm}(43,19.5,6.25,10,55,8,12.5$, $24,15.5,5,35$ and $29 \mathrm{~mm}$ ). All fish were counted and identified up to species level. Also in February 2015, the possible horizontal and vertical migration of zooplankton was also studied. For this, a SchindlerPatalas (volume of $30 \mathrm{~L}$ ) trap was used to obtain zooplankton densities. Densities were compared between the open water and an area dominated by submerged macrophytes and emergent macrophytes, and between the water surface and the bottom of the lake in the deepest point of the lake. In a period of $24 \mathrm{~h}$, densities of cladocerans (Daphnia) and copepods (Acanthocyclops) were measured once during night- (12 a.m.) and daytime (12 p.m.).

In February 2015, a grazing experiment was carried out to evaluate the impact of zooplankton on phytoplankton in general and on cyanobacteria in particular. Polyethylene bottles $(500 \mathrm{~mL})$ were filled with zooplankton-free lake water (filtered over a $64 \mu \mathrm{m}$ nylon mesh). Three treatments were prepared in triplicate: addition of cladocerans (Daphnia, 10 individuals $\mathrm{L}^{-1}$ ), addition of copepods (Acanthocyclops, 10 individuals $\mathrm{L}^{-1}$ ), and no addition of zooplankton (control). In order to eliminate the indirect enhancement of phytoplankton growth rates by nutrient excretion of zooplankton, the nutrients $\mathrm{N}$ and $\mathrm{P}$ were added in each treatment $\left(770 \mu \mathrm{g} \mathrm{L}^{-1}\right.$ as $\mathrm{K}_{2} \mathrm{HPO}_{4}, 7 \mathrm{mg} \mathrm{N} \mathrm{L}{ }^{-1} \mathrm{~N}$ as $\left.\mathrm{NaNO}_{3}\right)$. The bottles were randomly attached to an aluminum frame and incubated horizontally in the lake just below the water surface. To avoid photoinhibition or UV stress, a double folded shadow mesh was secured above the frame to reduce the light intensity to about $10 \%$ of the direct solar irradiance. After two days of incubation, the concentration of Chl $a$ and the cyanobacterial marker pigment phycocyanin in each bottle 
were measured in vivo using a fluorometer (AquaFluor, TurnerDesigns).

\subsection{Statistical analyses}

The R software was used for statistical analyses. For the zooplankton grazing and migration assay, ANOVA was used in combination with Tukey's post-hoc test.

\section{Results}

Mean minimum and maximum day temperatures between 1972 and 2009 were 12.2 and $24.5^{\circ} \mathrm{C}$, respectively (Fig. 1a). Mean day temperature was $17.7^{\circ} \mathrm{C}$ and was relatively constant throughout the year (Table 1 ). The daily maximum temperature was clearly higher and the minimum temperature lower, however, in August. The mean yearly rainfall was $619 \mathrm{~mm} \mathrm{year}^{-1}$ with two maxima in April $(93 \mathrm{~mm})$ and November $(67.2 \mathrm{~mm})$ and the lowest rainfall generally observed in August $(12.8 \mathrm{~mm}$ ) (Fig. 1b). Wind speed was also higher around August. During all months, the potential reference evapotranspiration exceeded the rainfall. August, the driest month, had at the same time the highest evapotranspiration rate $(159 \mathrm{~mm})$ (Fig. 1b).

Mean lake water temperature was $21.4^{\circ} \mathrm{C}$, which is substantially higher than the mean air temperature (Fig. $1 \mathrm{a}, \mathrm{c}$ ). Water temperature showed a slight decrease of $2.4^{\circ} \mathrm{C}$ in the period July to September, probably as a result of increased evaporation rates. Water temperature decreased gradually with depth and differed on average $1.1{ }^{\circ} \mathrm{C}$ between the surface water layer and the bottom, with a maximal difference of $3.0{ }^{\circ} \mathrm{C}$ in November. Mean oxygen concentration was $7.3 \mathrm{mg} \mathrm{L}^{-1}$ near the water surface and only $1.0 \mathrm{mg} \mathrm{L}^{-1}$ near the bottom (data not shown). At an elevation of $2300 \mathrm{~m}$ above sea level and a water temperature of $21{ }^{\circ} \mathrm{C}$, the oxygen concentration in equilibrium with the atmosphere is $6.7 \mathrm{mg} \mathrm{L}^{-1}$. Thus oxygen concentrations were slightly supersaturated near the water surface but depleted in bottom waters.

The bathymetrical survey revealed that the lake has a mean depth of $4.9 \mathrm{~m}$ and a maximum depth of $7.1 \mathrm{~m}$ (Fig. 2). Water depth increases

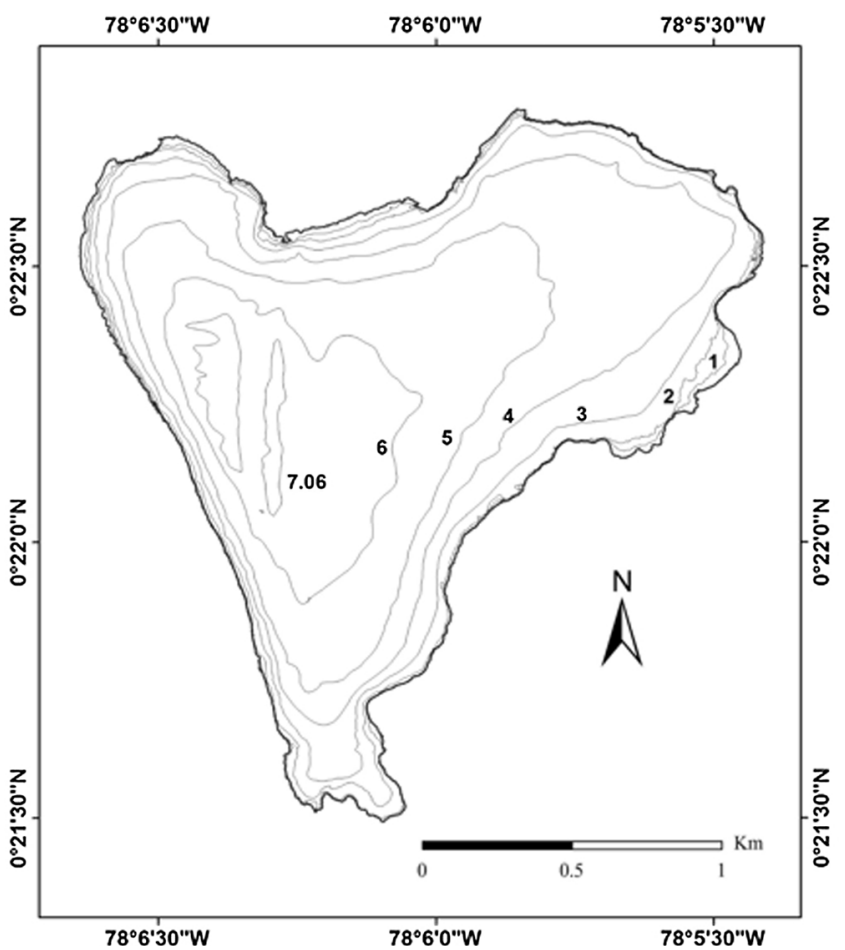

Fig. 2. Bathymetrical map. Map of the lake bottom of Yahuarcocha showing depth profile of the lake and indicating the deepest point $(7.06 \mathrm{~m})$. rapidly to a depth $>4 \mathrm{~m}$ close to the lake shore. The lake has a surface area of $2.6 \mathrm{~km}^{2}$ and a total volume of $12.710^{6} \mathrm{~m}^{3}$. The catchment of the lake covers an area of $21.2 \mathrm{~km}^{2}$. Direct inputs from precipitation (1.6 $10^{6} \mathrm{~m}^{3}$ year ${ }^{-1}$ ) and inflow from the catchment $\left(3.910^{6} \mathrm{~m}^{3}\right.$ year $^{-1}$, assuming a runoff coefficient of $30 \%$ ) should be sufficient to compensate for evaporative losses $\left(3.110^{6} \mathrm{~m}^{3}\right.$ year $^{-1}$, assuming an evaporation rate of $1030 \mathrm{~mm}$ year $^{-1}$, Günkel and Casallas, 2002).

Distribution of macrophytes within the lake was mapped in August 2013. Submerged macrophytes covered $1.4 \%$ of the lake area and consisted of Egeria densa, Elodea canadensis, Potamogeton pusillus and Myriophyllum aquaticum. Floating macrophytes covered $0.4 \%$ of the lake area and consisted of a floating vegetation dominated by Eichhornia crassipes and Azolla carolineana. Submerged and floating macrophytes were concentrated in shallow zones along the north shore of the lake. Emergent macrophytes covered $6 \%$ of the lake area and consisted of stands dominated by Schoenoplectus californicus, Typha domingensis and Arundo donax. They were mainly concentrated along the north shore and the southern corner of the lake. The emergent macrophytes in the southern corner form an important nesting habitat for aquatic birds.

Secchi depth was about $0.7 \mathrm{~m}$ in March 2014 and decreased gradually after June 2014 to reach a minimum of $0.3 \mathrm{~m}$ in March 2015 (Fig. 3a). Chl $a$ concentrations were relatively low in March 2014. At that time, the phytoplankton community consisted of a mixed community of diatoms, chlorophytes and cyanobacteria (Fig. 4a). Starting from July 2014, Chl $a$ concentrations increased and remained high until March 2015 (up to $185 \mu \mathrm{g} \mathrm{L}{ }^{-1}$ ). This increase in Chl $a$ concentration coincided with the onset of a bloom of the cyanobacterium Cylindrospermopsis. The Cylindrospermopsis bloom was reflected in an increase in echinenone concentrations, an indicator pigment for cyanobacteria (Fig. 3b). Analyses of Cylindrospermopsis biomass collected in the lake in July 2015 using LC-MS/MS indicated that the bloom produced the toxin cylindrospermopsin. Concentrations of cylindrospermopsin in the dry biomass were well above the limit of quantification and ranged from 525 to $1584 \mu \mathrm{g} \mathrm{g}^{-1}$.

TN concentrations varied between 1.22 and $2.73 \mathrm{mg} \mathrm{L}^{-1}$ (mean $1.90 \mathrm{mg} \mathrm{L}^{-1}$ ) and TP concentration between 36 and $98 \mu \mathrm{g} \mathrm{L}^{-1}$ (mean $56 \mu \mathrm{g} \mathrm{L}^{-1}$ ) (Table 2). Concentrations of DIN were very low and varied between 6 and $100 \mu \mathrm{g} \mathrm{L}^{-1}$ (mean of $49 \mu \mathrm{g} \mathrm{L}^{-1}$ ). Concentrations of SRP were also low and varied between 4 and $23 \mu \mathrm{g} \mathrm{L}{ }^{-1}$ (mean of $8 \mu \mathrm{g} \mathrm{L}^{-1}$ ). A large part of the TN consisted of DON (mean of 53\%) while the majority of the TP was associated with the particulate fraction (mean of $87 \%)$.

The zooplankton community in the lake as studied by net hauls was dominated by rotifers (predominantly Brachionus angularis and Keratella ssp.) and cyclopoid copepods (predominantly Acanthocyclops) (Fig. 4b). Cladocerans were rare. Daphnia spp. were present in the lake but in low abundances (mean of $1 \%$ of total zooplankton abundance). The dominant species was Daphnia pulex and it was relatively small in size $(0.5-1 \mathrm{~mm})$. In February 2015, zooplankton was sampled using a Schindler-Patalas trap at different locations in the lake to assess whether zooplankton used macrophytes or the deep water as a refuge for predation during daytime and emerged from this refuge at night. Zooplankton densities were not systematically higher within the macrophyte beds than outside the macrophyte beds nor higher near the lake bottom than near the water surface (Table 3). On the contrary, Daphnia abundance was higher in the open water than among the submerged $(\mathrm{n}=3, \mathrm{p}=0.014)$ and emergent $(\mathrm{n}=3, \mathrm{p}=0.018)$ macrophytes during the day and Daphnia abundance was higher near the bottom than near the water surface during the night $(n=3, p=0.012)$. Abundances of Daphnia determined using the Schindler-Patalas trap were always very low $\left(0.05-0.5\right.$ ind. $\left.\mathrm{L}^{-1}\right)$.

A grazing experiment was carried out in February 2015 to assess the impact of zooplankton on phytoplankton (Fig. 5). Despite the fact that zooplankton densities in the experimental bottles (10 Acanthocyclops or Daphnia $\mathrm{L}^{-1}$ ) were much higher than natural densities in the lake (see 


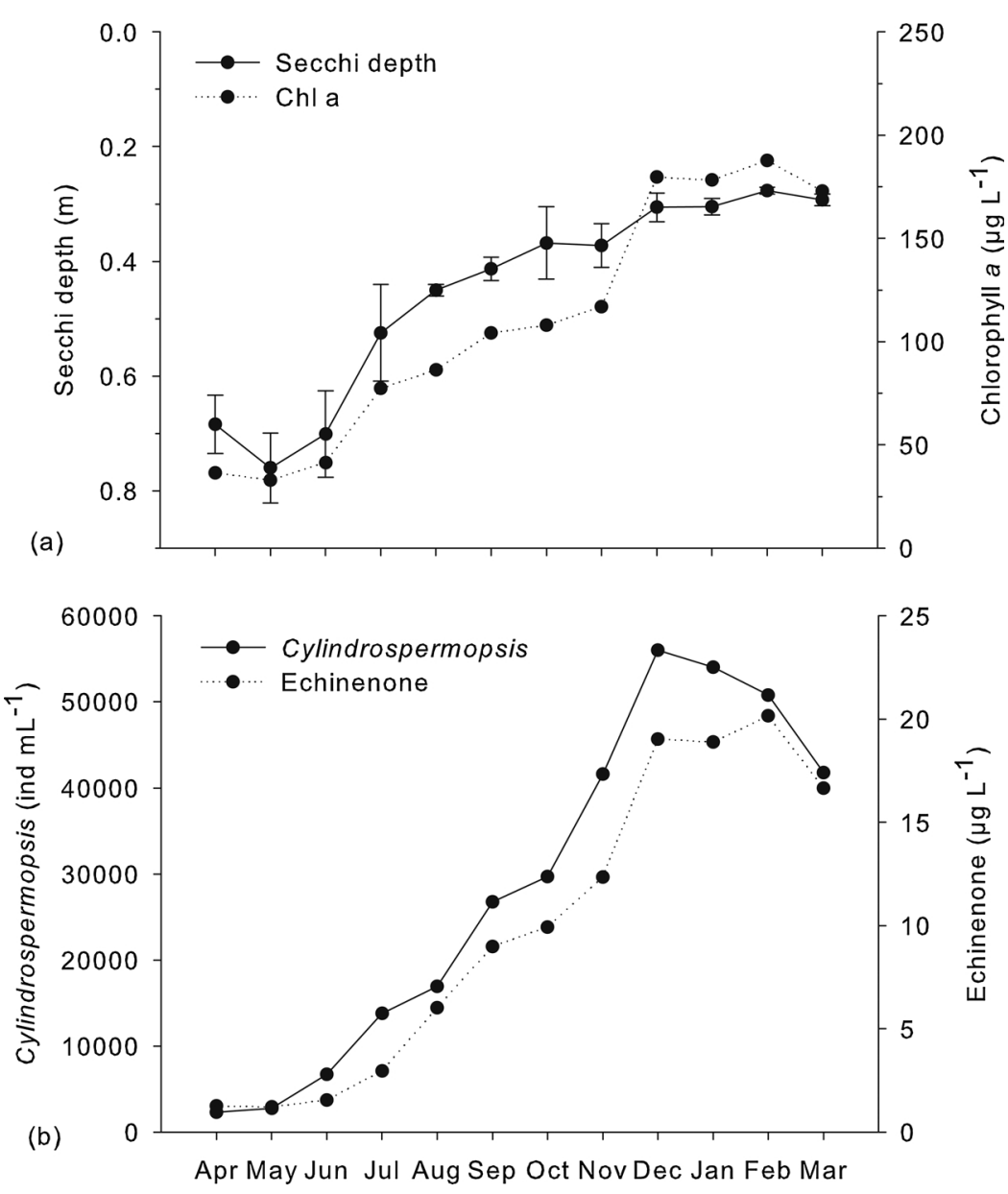

Fig. 3. Phytoplankton biomass. This graphs show (a) the annual variation in Secchi depth (m) and chlorophyll $a$ concentration $\left(\mu \mathrm{g} \mathrm{L}^{-1}\right)$ and (b) annual variation in the abundance of the cyanobacterium Cylindrospermopsis (ind $\mathrm{mL}^{-1}$ ) and echinenone concentration $\left(\mu \mathrm{g} \mathrm{L}^{-1}\right)$ in Yahuarcocha lake between March 2014 and March 2015.
Table 3), zooplankton still had a very limited impact on phytoplankton. After two days incubation, Acanthocyclops had no significant impact on the Chl $a$ concentration while Daphnia caused a $20 \%$ reduction in Chl $a$ ( $\mathrm{n}=3, \mathrm{p}=0.004)$. Both Acanthocyclops and Daphnia caused only a small and insignificant reduction $(5-7 \%)$ in the concentration of phycocyanin, an indicator pigment for cyanobacteria.

Sampling of fish using a multi-mesh size gill net in February 2015 revealed the presence of large numbers of the small poeciliids green swordtail and guppy (Xiphophorus hellerii and Poecilia reticulata, total 655 ind. caught in $30 \times 1.5 \mathrm{~m}$ net in $18 \mathrm{~h}$ ). The poeciliids were also caught in large numbers during sampling of zooplankton with the Schindler-Patalas trap within the macrophyte beds, indicating that it foraged among the macrophytes. In addition, goldfish (Carassius auratus, 6 ind.) and tilapia (Oreochromis niloticus, 6 ind.) were caught.

\section{Discussion}

Lake Yahuarcocha is a shallow lake that is clearly in a turbid state: Chl $a$ concentrations are quite high (ranging from 30 to $100 \mu \mathrm{g} \mathrm{L}^{-1}$ ), water transparency is low (Secchi depth $<1 \mathrm{~m}$ ) and submerged macrophytes cover only $1.4 \%$ of the lake area. During the study, the phytoplankton community shifted from a diverse community of diatoms, chlorophytes and cyanobacteria to a bloom dominated the cyanobacterium Cylindrospermopsis. Cylindrospermopsis blooms are common in eutrophic lakes and reservoirs in warm climates and pose a risk due to the production of toxins (e.g. Mowe et al., 2015). In the neotropics, Cylindrospermopsin producing Cylindrospermopsis strains were previously only reported in Brazil and Venezuela (Antunes et al., 2015; Mowe et al., 2015). In lake Yahuarcocha, the presence of the alkaloid toxin cylindrospermopsin was confirmed by LC-MS/MS analysis.
Throughout history it has been shown that cylindrospermopsin can cause severe sickness in humans (De la Cruz et al., 2013). This toxin could cause dermatitis in tourists swimming in the lake (Stewart et al., 2006) or intoxication of people consuming crayfish collected in the lake (Saker and Eaglesham, 1999). When Steinitz-Kannan (Steinitz-Kannan, 1979) visited Yahuarcocha lake in the 1970 's, she also reported a low Secchi depth but did not observe blooms of cyanobacteria. Thus, although Yahuarcocha lake has probably been in a turbid state for several decades, cyanobacteria blooms appear to be a more recent phenomenon. People living near the lake claim that floating green scum layers that are typical of cyanobacterial blooms started to appear during the past two decades.

In few words, Yahuarcocha is a turbid eutrophic lake suffering from cyanobacterial blooms and nutrients are at intermediate levels (1600 $\mu \mathrm{g} \mathrm{L}^{-1} \mathrm{TN}$ and $50 \mu \mathrm{g} \mathrm{L}^{-1} \mathrm{TP}$ ). At these nutrient concentrations, it is theoretically possible to shift a shallow lake from a turbid to a clear water state through biomanipulation (Jeppesen et al., 1990; Kosten et al., 2009). However, several properties of the food web of lake Yahuarcocha complicate the use of biomanipulation to realize a regime shift from a turbid to a clear water state.

The fish community in lake Yahuarcocha is dominated by poeceliids such as the green swordtail and guppy. These small fish have an omnivorous diet that also includes zooplankton (Meffe and Nelson, 1989). Because they are omnivorous, they can maintain a high biomass even when zooplankton food sources are low. Moreover, they are viviparous species that reproduce throughout the year. These properties result in a continuously high predation pressure on zooplankton. The fish community of lake Yahuarcocha lacks piscivorous species. As a result, there is no top-predator in the fish community that can control the large population of small, omnivorous fish (Jeppesen et al., 2007). 


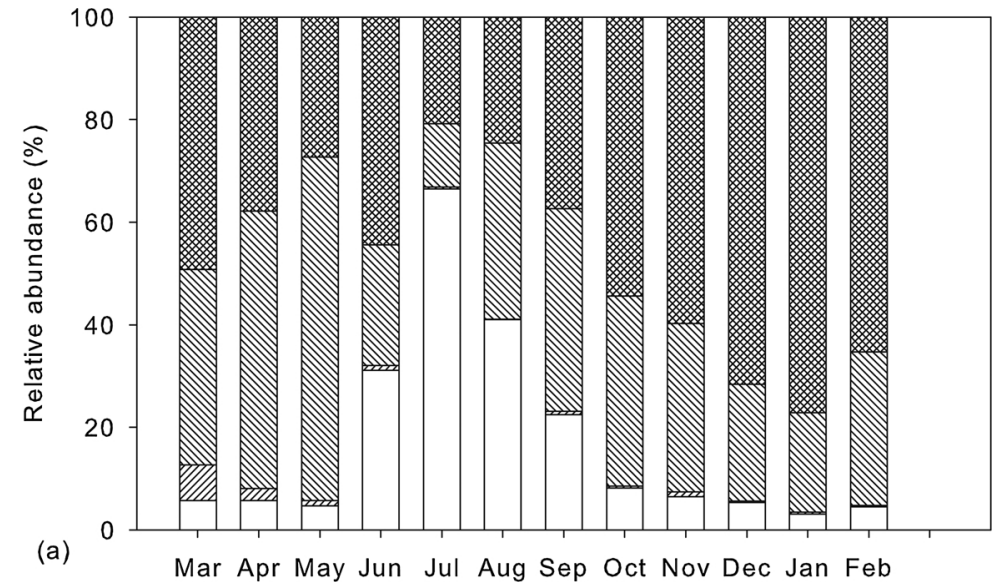

(a)

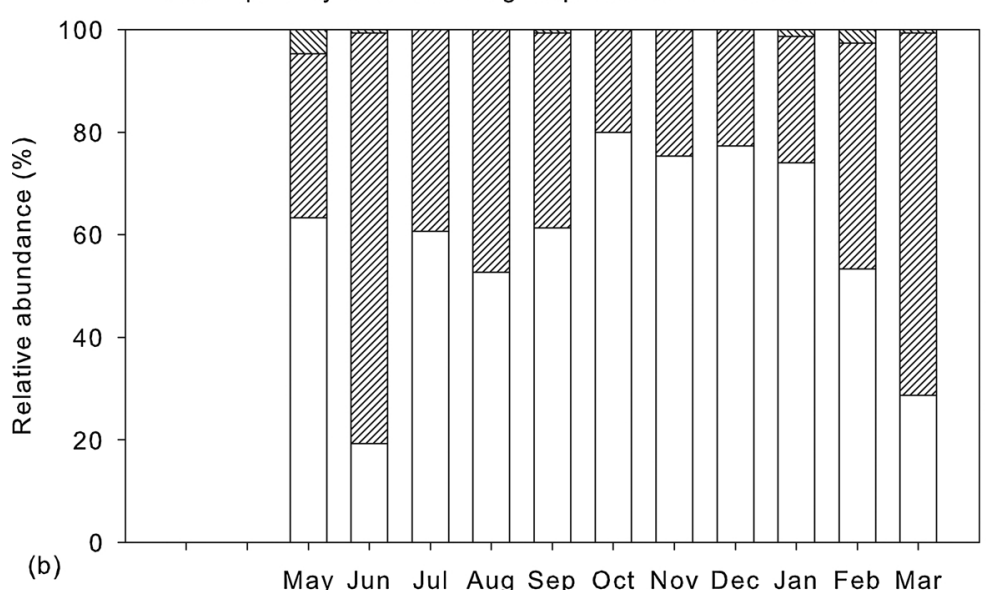

Fig. 4. Plankton species composition. Seasonal variation in relative abundance (\%) of different groups in (a) phytoplankton and (b) zooplankton community composition during this survey in Yahuarcocha lake.
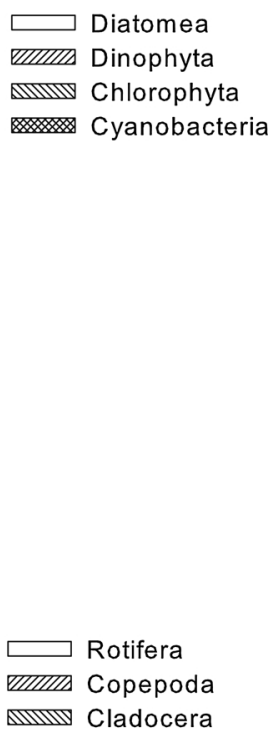

Table 2

Concentrations ( $\mu \mathrm{g} \mathrm{L}^{-1}$ ) of total nitrogen (TN) and phosphorus (TP), dissolved inorganic nitrogen (DIN), soluble reactive phosphorus (SRP) and dissolved organic nitrogen (DON) and phosphorus (DOP), as measured during seasonal monitoring of lake Yahuarcocha (March 2014-March 2015).

\begin{tabular}{llllll}
\hline \multirow{2}{*}{ Nutrient fraction } & & & Minimum & Maximum & Mean \\
\cline { 5 - 6 } \cline { 4 - 5 } Nitrogen & & & 1222 & 2731 & 1900 \\
& TN & & 32 & 100 & 63 \\
\multirow{3}{*}{ Phosphorus } & DON & & 650 & 2647 & 1004 \\
& TP & & 36 & 98 & 56 \\
& SRP & 5 & 23 & 8 \\
& DOP & 1 & 12 & 7 \\
\hline
\end{tabular}

Table 3

Spatial distribution of the copepod Acanthocyclops and the cladoceran Daphnia in lake Yahuarcocha in February 2015 (unit: ind $\mathrm{L}^{-1}$ ).

\begin{tabular}{|c|c|c|c|c|}
\hline & \multicolumn{2}{|c|}{ Acanthocyclops } & \multicolumn{2}{|l|}{ Daphnia } \\
\hline & Day & Night & Day & Night \\
\hline \multicolumn{5}{|l|}{ Lake shore } \\
\hline $\begin{array}{l}\text { Submerged } \\
\text { macrophytes }\end{array}$ & $2.2 \pm 0.8$ & $1.2 \pm 0.3$ & $0.04 \pm 0.04$ & $0.09 \pm 0.07$ \\
\hline $\begin{array}{l}\text { Emergent } \\
\text { macrophytes }\end{array}$ & $1.1 \pm 0.4$ & $1.9 \pm 0.5$ & $0.06 \pm 0.02$ & $0.20 \pm 0.07$ \\
\hline No macrophytes & $5.1 \pm 2.9$ & $1.7 \pm 0.2$ & $0.30 \pm 0.12$ & $0.14 \pm 0.07$ \\
\hline \multicolumn{5}{|l|}{ Open water } \\
\hline Surface & $2.8 \pm 0.3$ & $5.1 \pm 0.3$ & $0.10 \pm 0.03$ & $0.23 \pm 0.07$ \\
\hline Bottom & $5.2 \pm 3.4$ & $6.5 \pm 0.8$ & $0.29 \pm 0.11$ & $0.53 \pm 0.17$ \\
\hline
\end{tabular}

The zooplankton community is dominated by rotifers and cyclopoid copepods groups that cannot exert a strong top-down control on

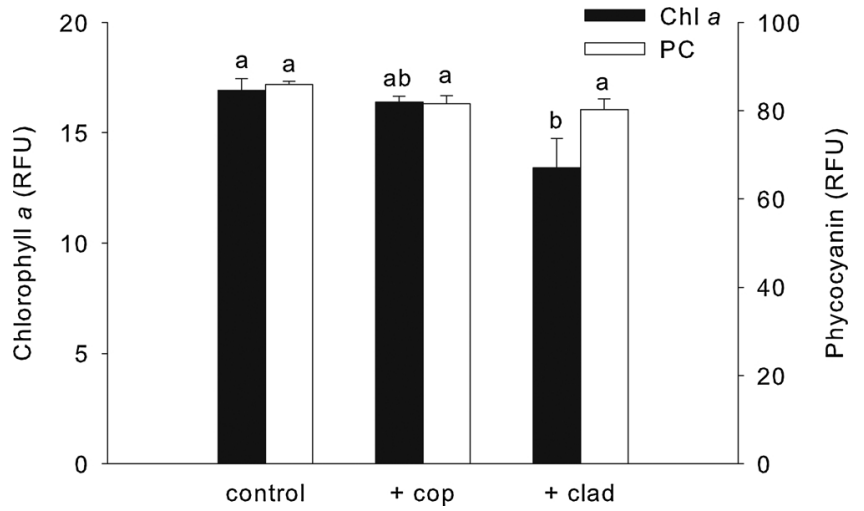

Fig. 5. Zooplankton grazing experiment. Results of in situ grazing experiment showing the relative concentrations (RFU) of chlorophyll $a(\mathrm{Chl} a$ ) and phycocyanin (PC) measured in vivo with a fluorometer in the different treatments (control: no zooplankton, + cop: addition of 10 Acanthocyclops ind $\mathrm{L}^{-1}$, + clad: addition of 10 Daphnia ind $\mathrm{L}^{-1}$ ) after two days of incubation. Letters above the bars denote treatments within the Chl a and PC data that are not significantly different at the $\mathrm{p} \leq 0.05$ level according to an ANOVA analysis.

phytoplankton. Although Daphnia pulex occurred in the lake, a large impact of this species on phytoplankton is unlikely because it was small $(0.5-1 \mathrm{~mm})$ and its abundance was very low. This zooplankton community composition is typical for highly eutrophic lakes (Hansson et al., 2007). Daphnia abundance was most likely low due to a combination of the presence of toxic cyanobacteria (low food quality) and predation by the small omnivorous poeceliids. Submerged macrophytes may offer a refuge to zooplankton from fish predation. Although submerged macrophytes occurred in the lake, they covered only a small part of the lake surface, too small to act as an important refuge. Even if abundance of submerged macrophytes in the lake would increase, it is unlikely that 
they could function as a refuge for Daphnia from fish predation because the poeceliids that dominate the fish community prefer to forage within the macrophyte vegetation (Iglesias et al., 2011). Indeed, poeceliids were often caught accidentally within macrophyte beds during sampling of zooplankton. Moreover, the fact that zooplankton abundance was not higher among macrophytes than in the open water confirms that macrophytes did not function as a refuge for zooplankton in the lake. On the contrary, Daphnia abundance was higher in the open water than among submerged as well as emergent macrophytes during the day.

Even if abundance of zooplankton were higher in the lake, top-down control of phytoplankton by zooplankton would be difficult because the phytoplankton community is dominated by the cyanobacterium Cylindrospermopsis. Several studies have shown that Cylindrospermopsis has a negative impact on Daphnia, although it is not clear whether this is related to the cylindrospermopsin toxin (Noguiera et al., 2004; Soares et al., 2009). Indeed, in the grazing assays, Daphnia had a weak impact on total phytoplankton (20\% reduction in Chl $a$ over two days), and even weaker impact on cyanobacteria (5-7\% reduction of the pigment phycocyanin). This impact was limited despite the fact that zooplankton abundance in the treatments was higher than one order of magnitude in comparison with the lake abundance. Acanthocyclops also had no influence of phytoplankton, which is not surprising as cyclopoid copepods are primarily carnivorous. Thus, top-down control of phytoplankton would be limited even if zooplankton abundance increased an order of magnitude. The Cylindrospermopsis bloom in Yahuarcocha lake persisted for more than a year (it started in July 2014 and persisted until at least April 2016). Such a long-term persistence of blooms of Cylindrospermopsis is common in tropical climates, probably as a result of the stability of the climate (Baptista and Nixdorf, 2014). This persistence of cyanobacterial blooms limits possibilities for zooplankton to control phytoplankton.

The factors that prevent biomanipulation in lake Yahuarcocha are to a large extent the same as those that interfere with biomanipulation in tropical shallow lakes: a fish community that is dominated by small omnivorous species, macrophytes offer no refuge for zooplankton from fish predation, and cyanobacterial blooms persist for more than a year (e.g. Jeppesen et al., 2007; Teixeira de Mello et al., 2009). This suggests that Lake Yahuarcocha shares more similarities with subtropical than with temperate shallow lakes. Although the high elevation of the lake results in a relatively cool climate (mean air temperature of $17^{\circ} \mathrm{C}$ ), the water temperature of the lake is quite high $\left(21^{\circ} \mathrm{C}\right.$ ) and is comparable to that of lowland subtropical lakes (e.g. Teixeira de Mello et al., 2009). The higher water than air temperature is caused by the fact that solar heating during the day is faster than radiative cooling at night and has been noted in other tropical mountain lakes, such as the nearby lake San Pablo (Günkel and Casallas 2002). In addition to this relatively high water temperature, the lack of a cold season probably explains why the lake is more similar to a tropical than a temperate shallow lake: the lack of a cold season allows cyanobacterial blooms to persist for more than one year and allows tropical fish species to survive in the lake.

It is remarkable that the fish and macrophyte communities in lake Yahuarcocha are made up entirely of introduced, exotic species. In the case of fish, these exotic species include the African Nile tilapia, the Chinese goldfish and the Central American poeceliids green swordtail and guppy. The submerged and floating macrophytes originate from the northern hemisphere (Elodea canadensis and Potamogeton pusillus) or from the lowlands in eastern South Americas (Egeria densa, Myriophyllum aquaticum, Eichhornia crassipes and Azolla carolineana). The success of these exotic species in the lake is most likely due to a combination of the low diversity of native species and the fact that these native species are adapted to oligotrophic conditions (Cronk and Fuller, 2001). The low diversity of aquatic ecosystems of the high Andes has been ascribed to the small area and relatively young age of the Andes mountains, which limits speciation and colonization of lakes by species from temperate climates (Jacobsen and Terneus, 2001). The few species that do occur at this elevation are usually endemic species that are adapted to oligotrophic conditions (Anderson and MaldonadoOcampo, 2011), as for example the Andean catfish Astroblepus ubidiai (Vélez-Espino, 2005) or the many species of Isoetes that occur in nutrient-poor wetlands in the Andes (Luteyn, 1999). At least with respect to the fish community, these exotic species most likely exacerbate eutrophication and complicate biomanipulation in Yahuarcocha lake.

Even if the population of small fish in the lake could be controlled and the cyanobacteria dominance in the phytoplankton community would be broken, it is not sure that biomanipulation would be succesfull. Most of the lake is deeper than $3 \mathrm{~m}$ and areas $<3 \mathrm{~m}$ are rare. As a result, a large increase in water transparency would be required to allow submerged macrophytes to colonize a substantial part of the lake area. Moreover, low oxygen concentrations near the lake bottom and resuspension of sediments by fish may enhance internal eutrophication (Jeppesen et al., 2012).

\section{Conclusion}

Lake Yahuarcocha is a eutrophic turbid shallow lake that suffers from blooms of the cylindrospermopsin producing cyanobacterium Cylindrospermopsis. Despite the fact that the lake has a relatively cool mountain climate, the lake food web has more similarities with subtropical lakes than with temperate lakes. These similarities include a fish community that is dominated by small, omnivorous species that forage within submerged macrophyte beds, the lack of predatory fish and the occurrence of a persistent cyanobacterial bloom. Although nutrient concentrations in the lake allow for a shift from a turbid to a clear macrophyte-dominated state, these food web properties prevent stable ecosystem state shift by means of biomanipulation. Probably due to a low diversity of native species, the lake hosts many exotic species. The presence of exotic poeciliid fish species in the lake probably contributes to the stabilization of the turbid state of the lake.

\section{Acknowledgements}

This work was supported by the Flemish University Council (VLIRUOS) South Initiative project [grant number ZEIN2013Z140], the VLIRUOS Ecuador Biodiversity Network and the Flemish Agency for Innovation in Science and Technology. We are grateful to students from Universidad Técnica del Norte (Francisco Caicedo, Fausto Cifuentes, Santiago Cabrera, Joselyn Pabón, Estefanía Andrade, Henry Escaleras) and KU Leuven university (Jasper Blomme, Tine Mandonx, Pauline Saelens, Tim Tytgat) for their enthusiastic support during field work and analysis of samples.

\section{References}

Anderson, E.P., Maldonado-Ocampo, J.A., 2011. A regional perspective on the diversity and conservation of tropical Andean fishes. Conserv. Biol. 25, 30-39.

Antunes, J.T., Leão, P.N., Vasconcelos, V.M., 2015. Cylindrospermopsis raciborskii: review of the distribution, phylogeography, and ecophysiology of a global invasive species. Front. Microbiol. 6, 473.

Baptista, M.G., Nixdorf, B., 2014. Low disturbances favor steady state: case of cyanobacterial monodominance in a Brazilian coastal lagoon. Inland Waters 4, 243-254.

Burks, R.L., Jeppesen, E., Lodge, D.M., 2001. Littoral zone structures as Daphnia refugia against fish predators. Limnol. Oceanogr. 46, 230-237.

Carpenter, S.R., Christensen, D.L., Cole, J.J., Cottingham, K.L., He, X., Hodgson, J.R., Kitchell, J.F., Knight, S.E., Pace, M.L., Post, D.M., Schindler, D.E., Voichick, N., 1995 Biological control of eutrophication in lakes. Environ. Sci. Technol. 29, 784-786.

Cronk, Q.C.B., Fuller, J.L., 2001. Plant Invaders: The Threat to Natural Ecosystems. Earthscan Publications Ltd, United Kingdom.

De la Cruz, A.A., Hiskia, A., Kaloudis, T., Chernoff, N., Hill, D., Antoniou, M.G., He, X., Loftin, K., O’Shea, K., Zhao, C., Pelaez, M., Han, C., Lynch, T.J., Dionysiou, J.J., 2013. A review on cylindrospermopsin: the global occurrence, detection, toxicity and degradation of a potent cyanotoxin. Environ. Sci. Process Impacts 15, 1979-2003.

Downing, J.A., Prairie, Y.T., Cole, J.J., Duarte, C.M., Tranvik, L.J., Striegl, R.G., McDowell, W.H., Kortelainen, P., Caraco, N.F., Melack, J.M., Middelburg, J.J., 2006. The global abundance and size distribution of lakes ponds, and impoundments. Limnol. Oceanogr. 51, 2388-2397. 
Figueredo, C.C., Giani, A., 2009. Phytoplankton community in the tropical lake of Lagoa Santa (Brazil): conditions favoring a persistent bloom of Cylindrospermopsis raciborskii. Limnologica 39, 264-272.

Günkel, G., Casallas, J., 2002. Limnology of an equatorial high mountain lake-Lago San Pablo, Ecuador: the significance of deep diurnal mixing for lake productivity. Limnologica 32, 33-43.

Hansson, L.-A., Gustafsson, S., Rengefors, K., Bomark, L., 2007. Cyanobacterial chemical warfare affects zooplankton community composition. Freshw. Biol. 52, 1290-1301.

Hobbs, W.O., Hobbs, J.M.R., LaFrançois, T., Zimmer, K.D., Theissen, K.M., Edlund, M.B., Michelutti, N., Butler, M.G., Hanson, M.A., Carlson, T.J., 2012. A 200-year perspective on alternative stable state theory and lake management from a biomanipulated shallow lake. Ecol. Appl. 22, 1483-1496.

Iglesias, C., Mazzeo, N., Meerhoff, M., Lacerot, G., Clemente, J.M., Scasso, F., Kruk, C., Goyenola, G., García-Alonso, J., Amsinck, S.L., Paggi, J.C., de Paggi, S.J., Jeppesen, E., 2011. High predation is of key importance for dominance of small-bodied zooplankton in warm shallow lakes: evidence from lakes, fish exclosures and surface sediments. Hydrobiologia 667, 133-147.

Jacobsen, D., Terneus, E., 2001. Aquatic macrophytes in cool aseasonal and seasonal streams: a comparison between Ecuadorian highland and Danish lowland streams. Aquat. Bot. 71, 281-295.

Jeppesen, E., Søndergaard, M., Mortensen, E., Kristensen, P., Riemann, B., Jensen, H.J., Müller, J.P., Sortkjaer, O., Jensen, J.P., Christoffersen, K., Bosselmann, S., Dall, E., 1990. Fish manipulation as a lake restoration tool in shallow, eutrophic temperate lakes 1: cross-analysis of three Danish case-studies. Hydrobiologia 200/201, 205-218.

Jeppesen, E., Meerhoff, M., Jacobsen, B.A., Hansen, R.S., Søndergaard, M., Jensen, J.P., Lauridsen, T.L., Mazzeo, N., Branco, C.W.C., 2007. Restoration of shallow lakes by nutrient control and biomanipulation-the successful strategy varies with lake size and climate. Hydrobiologia 581, 269-285.

Jeppesen, E., Søndergaard, M., Lauridsen, T.L., Davidson, T.A., Liu, Z., Mazzeo, N., Trochine, C., Özkan, K., Jensen, H.S., Trolle, D., Starling, F., Lazzaro, X., Johansson, L.S., Bjerring, R., Liboriussen, L., Larsen, S.E., Landkildehus, F., Egemose, S., Meerhoff, M., 2012. Biomanipulation as a restoration tool to combat eutrophication: recent advances and future challenges. In: Woodward, G., Jacob, U., O'Gorman, E.J. (Eds.), Advances in Ecological Research: Global Change in Multispecies Systems Part 2. Elsevier, Amsterdam, pp. 411-488.

Joehnk, K.D., Huisman, J.E.F., Sharples, J., Sommeijer, B.E.N., Visser, P.M., Stroom, J.M., 2008. Summer heatwaves promote blooms of harmful cyanobacteria. Glob. Change Biol. 14, 495-512.

Kosten, S., Kamarainen, A., Jeppesen, E., van Nes, E.H., Peeters, E.T., Mazzeo, N., Sass, L., Hauxwell, J., Hansel-Welch, N., Lauridsen, T.L., Søndergaard, M., Bachmann, R.W., Lacerot, G., Scheffer, M., 2009. Climate-related differences in the dominance of submerged macrophytes in shallow lakes. Glob. Change Biol. 15, 2503-2517.

Kosten, S., Huszar, V.L., Bécares, E., Costa, L.S., van Donk, E., Hansson, L.A., Jeppesen, E., Kruk, C., Lacerot, G., Mazzeo, N., De Meester, L., Moss, B., Lürling, M., Nõges, T., Romo, S., Scheffer, M., 2012. Warmer climates boost cyanobacterial dominance in shallow lakes. Glob. Change Biol. 18, 118-126.

Landuyt, D., Lemmens, P., D’Hondt, R., Broekx, S., Liekens, I., De Bie, T., Declerck, S.A.J.,
De Meester, L., Goethals, P., 2014. An ecosystem service approach to support integrated pond management: a case study using Bayesian belief networks Highlighting opportunities and risks. J. Environ. Manage. 145, 79-87.

Luteyn, J.L., 1999. Páramos, A Checklist of Plant Diversity, Geographical Distribution and Botanical Literature. The New York Botanical Garden, New York.

Meerhoff, M., Clemente, J.M., Teixeira de Mello, F., Iglesias, C., Pedersen, A.R., Jeppesen, E., 2007. Can warm climate-related structure of littoral predator assemblies weaken the clear water state in shallow lakes? Glob. Change Biol. 13, 1888-1897.

Meffe, G.K., Nelson, F.F., 1989. An ecological overview of poeciliid fishes. Ecology and Evolution of Livebearing Fishes (Poeciliidae). pp. 13-31.

Moss, B., 2000. Biodiversity in fresh waters - an issue of species preservation or system functioning? Environ. Conserv. 27, 1-4.

Mowe, M.A.D., Mitrovic, S.M., Lim, R.P., Furey, A., Yeo, D.C.J., 2015. Tropical cyanobacterial blooms: a review of prevalence, problem taxa, toxins and influencing environmental factors. J. Limnol. 74, 205-224.

Noguiera, I.C., Saker, M.L., Pflugmacher, S., Wiegand, C., Vasconcelos, V.M., 2004. Toxicity of the cyanobacterium Cylindrospermopsis raciborskii to Daphnia magna. Environ. Toxicol. 19, 453-459.

Saker, M.L., Eaglesham, G.K., 1999. The accumulation of cylindrospermopsin from the cyanobacterium Cylindrospermopsis raciborskii in tissues of the Redclaw crayfish Cherax quadricarinatus. Toxicon 37, 1065-1077.

Sarmiento, G., Gaviria, S., Hooghiemstra, H., Berrio, J.C., Van der Hammen, R., 2008. Landscape evolution and origin of Lake Fúquene (Colombia): tectonics, erosion and sedimentation processes during Pleistocene. Geomorphology 100, 563-575.

Smith, V.H., 2003. Eutrophication of freshwater and coastal marine ecosystems: a global problem. Environ. Sci. Pollut. R. 10, 126-139.

Soares, M.C.S., Lürling, M., Panosso, R., Huszar, V., 2009. Effects of the cyanobacterium Cylindrospermopsis raciborskii on feeding and life-history characteristics of the grazer Daphnia magna. Ecotox. Environ. Saf. 72, 1183-1189.

Steinitz-Kannan, M., 1979. Comparative Limnology of Ecuadorian Lakes: a Study of Species Number and Composition of Plankton Communities of the Galapagos Islands and the Equatorial Andes. Ph.D. Dissertation. Ohio State University. 351 pp.

Stewart, I., Seawright, A.A., Schluter, P.J., Shaw, G.R., 2006. Primary irritant and delayed-contact hypersensitivity reactions to the freshwater cyanobacterium Cylindrospermopsis raciborskii and its associated toxin cylindrospermopsin. BMC Dermatol. 6.

Teixeira de Mello, F., Meerhoff, M., Pekcan-Hekim, Z., Jeppesen, E., 2009. Substantia differences in littoral fish community structure and dynamics in subtropical and temperate shallow lakes. Freshw. Biol. 54, 1202-1215.

Urrutia-Cordero, P., Ekvall, M.K., Hansson, L.-A., 2016. Controlling harmful cyanobacteria: taxa-specific responses of cyanobacteria to grazing large-bodied Daphnia in a biomanipulation scenario. PLoS One 11, e0153032.

Vélez-Espino, L.A., 2005. Population viability and perturbation analyses in remnant populations of the Andean catfish Astroblepus ubidiai. Ecol. Freshw. Fish 14, 125-138.

Williams, P., Whitfield, M., Biggs, J., Bray, S., Fox, G., Nicolet, P., Sear, D., 2003. Comparative biodiversity of rivers, streams, ditches and ponds in an agricultural landscape in Southern England. Biol. Conserv. 115, 329-341. 